Гура В. Л., к.е.н., доцент Київський національний університет імені Тараса Шевченка м. Київ, Украӥна Новицький В. А., к.е.н. Університет державної фіскальної служби України м. Ірпінь, Київська область, Україна DOI: https://doi.org/10.30525/978-9934-26-028-5-4

\title{
ВАЖЛИВІСТЬ ЕКСПОРТНОГО КОНТРОЛЮ ТОВАРІВ І ТЕХНОЛОГІЙ ПОДВІЙНОГО ВИКОРИСТАННЯ
}

Проблема експортного контролю товарів і технологій подвійного використання, а також військового застосування завжди носила міжнародний характер і $є$ надзвичайно складною, оскільки передбачає дотримання правил багатьох торгівельних режимів, обізнаність щодо різних принципів та виключень.

Основними цілями експортного контролю є:

- протидія ризикам розповсюдження ЗМЗ (зброї масового знищення);

- сприяння мирному розвитку хімічних, біологічних та ядерних технологій;

- протидія тероризму шляхом встановлення належного державного контролю за здійсненням міжнародних передач товарів військового призначення та пов'язаних 3 ними товарів подвійного використання;

- встановлення правил добросовісної конкуренції (fair trade).

Тому ми можемо стверджувати, що експортний контроль це «певний виняток», який вимагає розуміння повної картини принципів міжнародної торгівлі, адже є як економічні фактори, так і неекономічні (геополітичні, екологічні, суспільні) впливу на країни.

Запровадження системи експортного контролю та дотримання усіма суб'єктами ринку міжнародних режимів, правил, розпоряджень і постанов формує обізнаність, а також відповідальне ставлення до національної та світової безпеки, тому що 
РХБЯ (CBRN) товари та технології $є$ одночасно надзвичайно ефективними для розвитку інноваційних технологій, а можуть зруйнувати не лише певну територію, але й весь світ.

РХБЯ - це радіаційні, хімічні, біологічні та ядерні товари і технології, які мають подвійне застосування: у мирних та немирних цілях.

Таким чином, експортний контроль сьогодні є невід'ємною частиною торгівлі, а також підприємництва, оскільки передбачає імпорт, експорт, транспортування РХБЯ товарів і технологій. У свою чергу, це передбачає дотримання правил економічної безпеки для сталого розвитку підприємств та їх функціонування у законодавчому полі.

Експортний контроль формує три ефективні питання для підприємців, які дають можливість працювати у законодавчому полі, а саме:

1. Що імпортуємо, експортуємо або транспортуємо: які саме товари та технології? Тобто детальний аналіз усіх характеристик i властивостей.

2. Навіщо: кінцеве (-i) призначення - аналіз можливих сфер застосування.

3. Хто: кінцевий (-i) користувач (-i) - дослідження бізнеспартнерів або країн на предмет міжнародних санкцій чи певних заборон, обмежень тощо.

Для глобальної гармонізації підходів у сфері експортного контролю $\epsilon$ запровадження контрольних списків багатьма країнами. Ці списки створюють сприятливі умови для країнучасниць міжнародних режимів для досягнення спільного розуміння ключових елементів функціонування систем експортного контролю, таких, наприклад, як принцип всеосяжного («catch-all») контролю [1].

Міжнародна система експортного контролю включає п'ять міжнародних режимів, а саме:

1. Австралійська група, АГ (Australia Group, AG) - нерозповсюдження хімічної та біологічної зброї. Заснована у 1985 році [2]. 
2. Режим контролю за ракетними технологіями, РКРТ (Missile Technology Control Regime, MTCR). Заснований у 1987 році [3].

3. Група ядерних постачальників, ГЯП (Nuclear Suppliers Group, NSG). Заснована у 1974 році [4].

4. Вассенаарська домовленість, ВД (Wassenaar Arrangement, WA) - сприяє прозорості національних режимів експортного контролю щодо звичайної зброї та товарів і технологій подвійного використання. Заснована у 1995 році [5].

5. Комітет Цангера, КЦ (Zangger Committee, ZC) відомий як комітет ядерних експортерів-учасників Договору про нерозповсюдження ядерної зброї (ДНЯЗ), було створено у 1971 р. після того, як у 1970 р. набув чинності ДНЯЗ [6].

Отже, ми бачимо, що світова система експортного контролю $є$ досить регульованою, тому що покликана забезпечити безпечні умови для суб'єктів господарювання, а також мирний розвиток світу, недопущення виробництва та розповсюдження різних видів РХБЯ озброєнь.

Так, методами здійснення державного експортного контролю в Україні є:

1) ідентифікація товарів, що передбачає встановлення відповідності конкретних товарів, які $є$ об'єктами міжнародних передач, найменуванню та опису товарів, внесених до списків товарів, що підлягають державному експортному контролю;

2) надання дозволів чи висновків на здійснення міжнародних передач товарів або проведення переговорів щодо здійснення таких передач;

3) здійснення митного контролю та митного оформлення товарів відповідно до законодавства;

4) застосування санкцій до суб'єктів господарювання, які порушили порядок здійснення таких передач, установлений актами законодавства в галузі експортного контролю [7].

Водночас, на сучасному етапі розвитку світового та національного ринку товарів та технологій подвійного призначення $\epsilon$ наступні проблеми: 
1. Маркування товарів та технологій, які можуть мати відношення до товарів і технологій подвійного призначення, що потребує додаткового контролю за експортними операціями відповідних компаній-виробників;

2. Ускладнена та довготривала процедура експертної оцінки товарів і технологій щодо приналежності їх до подвійного призначення у випадку неоднозначності експортно-імпортної операції;

3. Значний часовий лаг щодо внесення змін до переліку товарів та технологій подвійного призначення.

Отже, важливість дотримання усіх міжнародних і національних правил експортного контролю товарів та технологій подвійного використання підприємцями є запорукою безпечного розвитку не лише бізнесу, а й світу. 3 боку урядів державучасниць міжнародних режимів $\epsilon$ необхідність постійного моніторингу глобальної ситуації щодо розвитку товарів і технологій подвійного призначення, що вимагає оновлення контрольних списків. Адже сучасні досягнення науки та техніки $\epsilon$ надзвичайно динамічними i багатофункціональними, а нові інноваційні зміни, крім позитивних моментів, можуть породжувати й негативні, які несуть певні ризики та загрози. Тому система експортного контролю відіграє надзвичайно важливу роль у забезпеченні національної безпеки та добробуту держав.

\section{Література:}

1. Michel Q., Paile S., Tsukanova M., Viski A. Controlling the Trade of DualUse Goods: A Handbook, P.I.E. Peter Lang, Non-Proliferation and Security. No. 9, Brussels, 2013.

2. The Australia Group. Available at: https://www.dfat.gov.au/publications/ minisite/theaustraliagroupnet/site/en/index.html.

3. Missile Technology Control Regime. Available at: https://mtcr.info.

4. Nuclear Suppliers Group. Available at: https://www.nuclearsuppliersgroup.org/en.

5. Wassenaar Arrangement. Available at: https://www.wassenaar.org.

6. Zangger Committee. Available at: http://zanggercommittee.org.

7. Стаття 5 Закону України «Про державний контроль за міжнародними передачами товарів військового призначення та подвійного використання». URL: https://zakon.rada.gov.ua/laws/show/549-15\#Text. 